\title{
（15） 日本の炭鉱の粉じん制御技術の現況
}

\author{
(財)石炭エネルギーセンター 中 西達 夫・小森 弘 雄 \\ 早稲田大学理工学部 名 古 屋 俊 \pm
}

\section{1.はじめに}

日本の石炭鉱業における災害率は、他産業と比較しても 遜色がないほど、着実に減少してきた。また、坑内作業場 の粉じんに関する作業環境についても、海外の粉じん制御 技術の導入、及び法的規制の強化 - 拡充等により、漸次改 善されている。しかしながら、機械化掘進箇所、長壁式採 炭箇所では、自然条件の変動等により、常に良好な環境条 件に維持するのは難しい状沉にある。

我が国のじん肺患者の新規有所見者数（管理 1 であった もので管理 2 以上に決定された者の数）は、1995年は653名 であり、そのうち石炭鉱業は 3 名であうた。絶対数は僅か であるが、じん肺健康診断実施労働者総数は、製造業、鉱 業、建設業、その他産業を含めると、全体では約 213,000 名 であり、このうち、石炭鉱業は540名なので、新規有所見者 の発生率は、全体平均の約1.8倍となっている。今後共、じ 几肺の新規有所見者数の発生数の減少を図るため、坑内作 業場の環境改善に、一層尽力することが必要である。

石炭鉱業における粉じん対策については、通商産業省か ら1986年より石炭技術研究所が「粉じん抑制技術の開発」 のテーマで調査委託を受け、本質安全防爆型粉じん測定器、 呼吸保護具、集じん装置、採炭機械に係る粉じん抑制型ド ラムの開発等、主にハード面の開発を行った。また、1988 年からは鉣業労働災害防止協会が「粉じん発生状況把握と 作業環境対策調査」のテーマで、坑内作業環境の実態調査、 測定方法の検討、及び噴霧器や防じんネット等による抑制 対策試験等主にソフト面の調査を実施した。1995年からは ハード・ソフトの一元化によって、より作業環境の改善を 図るため、両調查委託事業共、石炭技術研究所に集約して 実施されることになった。1997年 7 月からは石炭技術研究 所、日本石炭協会及び石炭技術開発センターの 3 団体が統 合され、石炭エネルギーセンター(JCOAL) が設立されたので、 上記事業は、現在、JCOALに引き継がれ実施中である。

本論文では、我が国石炭鉱業の粉じんに関する法規制及 び粉じん濃度測定法・評価法を概観すると共に、上記事業 の成果についてその概要を述べ、今後の取り組みについて 検討したい。

\section{2. 粉じんに関する法規制}

粉じんに関する保安、或いは労㗢衛生に関して事業者及 び労働者が遵守すべき事項については、石炭鉱山、金属鉱 山等では「鉱山保安法」、その他産業では「労働安全衛生 法」により定められている。また、粉じん作業従事労働者
の健康管理等については、全産業共通して「じん肺法」に より、対策が行われている。終戦後、産業再生をテーマと した金属釷山等の労使間協議で、けい肺の予防及び補償に ついて、立法化への強い要望が出された。これらの動きを 受けて、1955年に「けい肺及び外傷性せき髄障害に関する 特別保護法」が制定された。これは我が国で初めて職業病 対策が単独の法律として制定施行された画期的なものであ る。そして、けい肺のみならず、広くじん肺全体について、 更に適正な予防及び健康管理の措置を講ずる必要が認めら れ、1960年に「じん肺法」が制定されたのである。

鉱山保安法は1949年に制定され、鉱業権者及び釷山労働 者の義務事項、坑内で使用する機械、器具等に関する制限、 各鉱山における保安規程の制定、保安教育の実施、保安委 員会の設置等が定められている。さらに、鉱山保安規則に より、各事項について具体的に規定されている。石炭鉱山 の粉じんに係る鉱山保安規則の規制は、大略下記のとおり、 年々強化・拡充されてきた。

1949 年

○炭じんに関する保安教育

○炭じん抑制の散水

○衝撃式削岩機使用時の粉じん防止装置又 は防じんマスクの備え付け

1950 年

1952 年 ○湿式削岩機の全面使用

1979 年 @粉じんに関する保安教育

○粉じんの飛散を防止するため、散水、集 じんその他の適当な措置

○適当な措置が困難な場合等の防じんマス クの使用指示

○坑外作業場の粉じん濃度測定及び測定結 果の記録保存

1986 年 けい酸質区域の指定制度を廃止し、「け い酸質区域」を「坑内作業場」に変更

○適当な措置を講じた場合であって、なお 保安のため必要があるときの防じんマス クの使用指示

1991 年 ○坑内作業場の粉じん濃度測定及び測定結 果の記録保存

1992 年 ○坑外作業場の粉じん濃度測定結果の評価 及び措置の義務化

（注）坑内作業に関するものはの印、坑外屋内作業に関 するものは○印、両方に適用されるものは○印で示 した。 


\section{3. 粉じん濃度測定法・評価法}

1984 年通商産業省環境立地局は、石炭鉱山、金属鉱山等 における粉じん濃度測定について、「鉣山における粉じん 濃度測定要領」を制定した。その後、鈗業労働災害防止協 会に設置した委員会において、坑内作業場における粉じん 濃度測定方法の検討が行われ、1986年に「鉱山における粉 じん濃度測定マニュアル」が作成された。1994年には、そ の後の検討結果を反映し、一部補足、見直しが行われた。

作業場の粉じん濃度測定法は、環境濃度測定法と個人暴 露濃度測定法とに大別される。英国、フランス、米国等で は環境濃度測定に加え、個人暴露濃度測定が行われている が、我が国はドイツと同様、環境濃度測定法であり、個人 暴露濃度測定法は、ほとんど実施されていない。我が国の 環境濃度測定法は、作業場を近似する作業範囲に分割して、 これを「単位作業場所」とし、吸入性粉じんが当該場所の 作業者に与える影響度を、測定により周知する方法（A 測 定法）である。A 測定法のポイントは下記の通りである。

(1) 単位作業場所内に無作為に 5 点以上の測定点を設定す る。

(2) 測定点間の間隔は等距離間隔とする。

(3) 測定点間の測定時間は等時間間隔とする。

(4) 測定は、正常な作業帯に行う。

(5) 測定時間は、最低 1 時間以上とし、作業サイクルを考 慮して決定する。

（6) 全測定点についての測定は、連続した 2 作業日につい て行うことが望ましい。1 日間測定の場合、日間変動 を考慮して評価しなければならない。

また、A 测定法のみでは、吸入性粉じんの発生状況、作 業姿勢、作業方法等による労働者の高濃度暴露を見逃す恐 れがある場合には、労働者の暴露が最大と考えられる場所 と時間帯における濃度の 15 分間の平均濃度測定（B 測定 法）を行い、この結果を、A測定法の結果に加味して総合 評価しなければならない。

我が国の環境濃度測定結果の評価については、管理濃度 $\mathrm{E}$ が評価基準である。 $\mathrm{A}$ 測定法では、各測定点の測定值の
分布が、対数正規分布型となることに着目し、測定值の対 数変換を行い、幾何平均值 $\mathrm{M}$ 及び幾何標準偏差 $\sigma$ を求め、 統計的処理により第 1 評価值 $\mathrm{E}_{1}$ 、第 2 評価値 $\mathrm{E}_{2}$ を算出し、 管理濃度 $\mathrm{E}$ との比較により、作業環境を第 1 管理区分、第 2 管理区分及び第 3 管理区分に評価する。幾何標準偏差が 評価の対象とされているのは、作業環境の状態は、平均濃 度のみではなく、粉じん濃度の場所的、時間的変動の大き さを勘案して、評価を行う必要があるとの考え方からであ る。 $\mathrm{E},<\mathrm{E}$ は第 1 管理区分、 $\mathrm{E}_{2} \leqq \mathrm{E} \leqq \mathrm{E}$ 、は第 2 管理区分、 $\mathrm{E}<\mathrm{E}_{2}$ は第 3 管理区分である。 $\mathrm{B}$ 測定法では、1 5 分間の 平均濃度 $\mathrm{C}_{\mathrm{B}}$ を管理濃度 $\mathrm{E}$ と比較し、 $\mathrm{C}_{\mathrm{B}}<\mathrm{E}$ は第 1 管理区 分、 $\mathrm{E} \leqq \mathrm{C}_{\mathrm{B}} \leqq 1.5 \mathrm{E}$ は第 2 管理区分、1.5E $<\mathrm{C}_{\mathrm{B}}$ は第 3 管 理区分である。両測定法を実施した場合は、悪い方の管理 区分で評価しなければならない。管理濃度は各国の暴露基 準、作業環境管理技術の実用可能性、その他作業環境管理 に関する国際的動向等を考慮して、作業環境管理の目的に 沿うよう「行政的見地」から設定されたものである。吸入 性粉じんの管理濃度 $\mathrm{E}$ は次式により求める。

$$
\mathrm{E}=\frac{2.9}{0.22 \times \mathrm{Q}+1} \quad\left(\mathrm{mg} / \mathrm{m}^{3}\right)
$$

（注；Qは遊離けい酸含有率(\%)を表す。）

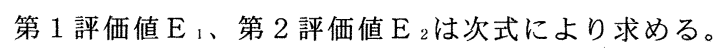
但し、ここでは 2 日間測定の場合を示す。

$\log \mathrm{E}_{1}=\log \mathrm{M}+1.645 \log \sigma$

$\log \mathrm{E}_{2}=\log \mathrm{M}+1.151 \log ^{2} \sigma$

第 1 表に、管理区分と管理区分に応じて講ずべき措置を 示す。作業環境が第 2 管理区分又は第 3 管理区分の場合は、 作業環境を第 1 管理区分に改善するため、必要な措置を講 じなければならない。作業環境が第 1 管理区分となるまで、 測定 $\rightarrow$ 評価 $\rightarrow$ 措置 $\rightarrow$ 測定のサイクルを繰り返し実施しなけ ればならないのである。選炭工場など石炭鉱山の坑外屋内 作業場においては、1992年に測定結果の評価に基づいて、 必要な措置を講ずることが義務づけられた。

第 1 表 管理区分と管理区分に応じて講ずべき措置

\begin{tabular}{|c|c|c|c|}
\hline $\begin{array}{l}\text { 管理 } \\
\text { 区分 }\end{array}$ & 作業場所の状態 & $\begin{array}{cc}\text { 評 価 } \\
\end{array}$ & 講ずべき措 置 \\
\hline 1 & $\begin{array}{l}\text { 当該単位作業場所の殆どの場（95\%以 } \\
\text { 上）て吸入性粉じんの濃度が管理濃度を } \\
\text { 超えない状態。 }\end{array}$ & $\begin{array}{l}\text { 作業環境管理が適切 } \\
\text { であると判断される。 }\end{array}$ & 現在の管理の継続的維持に努める。 \\
\hline 2 & $\begin{array}{c}\text { 当該単位作業場所の吸入性粉じんの濃 } \\
\text { 度の平均が管理濃度を越えない状態。 }\end{array}$ & $\begin{array}{l}\text { 作業環境管理になお } \\
\text { 改善の余地があると判 } \\
\text { 断される。 }\end{array}$ & $\begin{array}{l}\text { 施設、設備、作業工程又は作業方法の点検 } \\
\text { を行い、その結果に基づき、作業環境を改善 } \\
\text { するため必要な措置を講ずるよう努める。 }\end{array}$ \\
\hline 3 & $\begin{array}{c}\text { 当該単位作業場所の吸入性粉じんの濃 } \\
\text { 度の平均が管理濃度を超える状態。 }\end{array}$ & $\begin{array}{l}\text { 作業環境が適切でな } \\
\text { いと判断される。 }\end{array}$ & $\begin{array}{l}\text { (1) 施設、設備、作業工程又は作業方法の点 } \\
\text { 検を行い、その結果に基づき、作業環境を } \\
\text { 改善するため必要な措置を講ずる。 } \\
\text { (2) 呼吸保護具の使用 } \\
\text { (3) 健康診断の実施その他労働者の健康の保 } \\
\text { 持を図るため必要な措置を講ずる。 }\end{array}$ \\
\hline
\end{tabular}


4. 粉じん抑制技術の開発スケジュール

上記調査委託事業の試験項目は下記 5 項目に大別される。

(1) 調査

(2) 粉じん測定器の開発

(3) 呼吸保護具の開発

(4) 集じん装置の開発

（5）粉じん抑制型ドラムの開発

第 2 表に粉じん対策技術の開発スケジュールを示す。以

下、各試験項目について、その概要を述べる。

(1) 調查

海外調查では、英国、ドイッ、フランス、米国など海外 先進国の粉じん対策技術、粉じん測定器の仕様、粉じん濃 度測定法、並びに法規制などを調查した。また、実験室に おいて海外粉じん測定器の性能調查を行い、日本の粉じん 測定器との比較検討を行った。第 3 表に海外粉じん測定器 の性能調査の結果を示す。国により粉じん計の分粒粒径及 び測定法も異なっており、また、同じ作業環境であっても、 使用する粉じん測定器により、粉じん濃度が異なっている。
坑内作業環境の実態調查及び抑制対策試験では、過去 9 年間で延べ51山、181単位作業場所で 416 デー夕を収集した。 この間、本質安全防爆型相対濃度粉じん計（LD-1E）及び質 量濃度粉じん計（LV-5E）の開発に伴い、1991年「常時著し く粉じんが飛散する坑内作業場」の定期的な（1 回／6ヶ月） 粉じん濃度測定が義務づけられたので、各炭鉱の粉じん担 当者に測定方法の研修等を実施した。また、分析に係る負 担を軽減するため、相対濃度から質量濃度に変換するため の質量濃度変換係数 $\mathrm{K}$ 值 $\left(\mathrm{mg} / \mathrm{m}^{3} / \mathrm{cpm}\right)$ 、及び管理濃度を算 出するための遊離けい酸含有率 $\mathrm{Q}$ 值（\%）のグルーピング を行った。これは、作業内容別及び石炭鉱山別に $\mathrm{K}$ 值、 $\mathrm{Q}$ 值のグルーピングを行い、対数正規確率紙にプロットし、 累積度数 $85 \%$ に相当する $\mathrm{K}_{85}$ 及び $\mathrm{Q}_{85}$ を求めたものである。 第 4 表に $\mathrm{A}$ 炭鉱における $\mathrm{K}$ 值， $\mathrm{Q}$ 值のグルーピングの一例 を示す。 $\mathrm{K}$ 值はそれほど大きな差異は認められないが、 $\mathrm{Q}$ 值は作業内容別、炭鉱別によって大きな差異が認められる。 $\mathrm{Q}$ 值が高くなればなるほど、管理濃度は小さくなるので、 より厳しい粉じん対策が求められることになる。

第 2 表 粉じん対策技術開発スケジュール

\begin{tabular}{|l|l|l|l|l|l|l|l|l|l|l|l|l|}
\hline \multicolumn{1}{|c|}{ 試 験 項 目 } & 86 & 87 & 88 & 89 & 90 & 91 & 92 & 93 & 94 & 95 & 96 \\
\hline ( 1 ) 調查 & & & & & & & & & & & \\
1. 海外調査 (英、米、独、仏他) \\
2. 国内炭鉱坑内作業環境の実態調查及び抑制対策試験
\end{tabular}

第 3 表 諸外国の粉じん計、測定法等の比較

\begin{tabular}{|c|c|c|c|c|c|}
\hline 項 目 国 名 & 英 国 & ドイツ & フランス & 米 国 & 日 \\
\hline 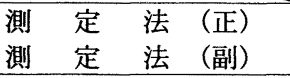 & $\begin{array}{l}\text { 環境濃度 } \\
\text { 個人暴露濃度 }\end{array}$ & 環境濃度 & \begin{tabular}{|l} 
環境濃度 \\
個人暴露濃度
\end{tabular} & $\begin{array}{l}\text { 個人暴露濃度 } \\
\text { 環境濃度 }\end{array}$ & 環境濃度 \\
\hline 粉 じ ん 計 & $\begin{array}{l}\text { MRE113A } \\
\text { Simped 70MK2 }\end{array}$ & $\begin{array}{l}\text { SFI BauartDrager } \\
\text { TMdigital } \mu \mathrm{P}\end{array}$ & $\begin{array}{l}\text { CPM } 3 \\
\text { CIP10 } \\
\end{array}$ & $\begin{array}{l}\text { 10mm ナ价将仍ロ } \\
\text { MRE113A }\end{array}$ & $\begin{array}{l}\mathrm{LV}-5 \mathrm{E} / \mathrm{LD}-1 \mathrm{E} \\
\mathrm{C}-30\end{array}$ \\
\hline 測 定 方 式 & 質量濃度 & $\begin{array}{l}\text { 質量濃度 } \\
\text { 相対濃度 }\end{array}$ & 質量濃度 & 質量濃度 & $\begin{array}{l}\text { 質量濃度 } \\
\text { 相対濃度 }\end{array}$ \\
\hline 分 粒 方 & $\begin{array}{c}\text { 多段平行板型 } \\
\text { (重力沈降） }\end{array}$ & $\begin{array}{c}\text { 多段平行板型 } \\
\text { (重力沈降) }\end{array}$ & $\begin{array}{l}\text { サイクロン型 } \\
\text { （遠心分離） }\end{array}$ & $\begin{array}{l}\text { サイクロン型 } \\
\text { (遠心分離) }\end{array}$ & $\begin{array}{l}\text { 慣性衝突型 } \\
\text { 多段平行板型 } \\
\text { (重力沈降) }\end{array}$ \\
\hline 分 粒 粒 径 $\mu \mathrm{m}$ & 7.07 & 5 & 5 & 10 & 7.07 \\
\hline $\begin{array}{l}\mathrm{C}-30 \text { の濃度を } 1 \mathrm{mg} / \mathrm{m}^{3} \text { と } \\
\text { した時の諸外国の粉じ } \\
\text { ん計の濃度の一例 }\end{array}$ & 1. 00 & 0.54 & 0.98 & 0.85 & 1.00 \\
\hline
\end{tabular}


第 4 表 $\mathrm{A}$ 炭鉱におけるK 值、Q值のグルーピングの例

\begin{tabular}{|c|c|c|c|c|c|}
\hline \multirow{2}{*}{\multicolumn{2}{|c|}{ 炭 鉱 別 }} & \multicolumn{4}{|c|}{ 作 業 内 容 別 } \\
\hline & & 機械化採炭 & 沿眉掘進 & 岩石掘進 & B C 積 替 \\
\hline \multirow{3}{*}{$\begin{array}{l}\text { A } \\
\text { 炭 } \\
\text { 鉱 }\end{array}$} & $\begin{array}{l}\text { 設 定 K 値 } \\
\left(\mathrm{mg} / \mathrm{m}^{3} / \mathrm{cpm}\right)\end{array}$ & 0.030 & 0.023 & - & 0.014 \\
\hline & $\begin{array}{c}\text { 設 定 Q 值 } \\
(\%)\end{array}$ & 20.2 & 23.0 & 29.0 & - \\
\hline & $\begin{array}{l}\text { 管 理 䈨 度 } \\
\left(\mathrm{mg} / \mathrm{m}^{3}\right)\end{array}$ & 0.53 & 0.47 & 0.39 & \\
\hline
\end{tabular}

\section{(2) 粉じん測定器の開発}

従来は、耐圧防爆型質量濃度粉じん計（LVS-10B）を使用 していたが、重量が $25 \mathrm{~kg}$ あ、持ち運びに非常に不便であ った。そこで、近年の通信機器の進歩により、本質安全防 爆型相対濃度粉じん計（LD-1E）及び本質安全防爆型質量濃 度粉じん計 $(\mathrm{LV}-5 \mathrm{E})$ の開発を行った。これらの小型・軽量

(5kg程度) の粉じん測定器の開発により、炭鉱坑内の粉じ ん濃度測定に係る負担が、著しく軽減された。

現在、粉じん濃度の集中監視化を行うため、定置式粉じ ん計 (LD-2E) の現場試験を実施中である。当初の主目的は、 環境条件の比較的良好な作業場において、粉じん濃度の集 中監視化を行い、測定業務の負担を軽減することであった。 しかし、測定業務に係る負担の軽減のみではなく、粉じん 濃度の集中監視化は、粉じん濃度の連続的な把握が可能と なるので、現行の測定法を補完することができ、粉じんに 関するきめ細かな作業環境管理の実施が可能となった。

\section{（3）呼吸保護具の開発}

本質安全防爆型電動ファン付呼吸保護具（全面型、半面 型）及び電動ファン内蔵型防じんマスクを開発し、現場試 験を実施した。使用者のアンケート調查の結果では、切削 機械のオペレータなどには適用性はあるが、動作の大きい 力作業では、ヘルメット、送風機の重量が重い、視野が狭 くなるなど適用性は余りないと判断される。現在、実用化 には至っていないが、作業箇所、作業形態を選んで、ある 程度中長期に使用してみて、実用化を促進することが望ま れる。軽量化等に関しては、今後の課題と考える。

\section{（4）集じん装置の開発}

海外技術を導入して国産化した乾式集じん装置の軽量 ・ 小型化を行い、処理風量 $500 \mathrm{~m}^{3} / \mathrm{min}$ の固定式集じん装置の開 発を行うと共に、吸出し通気用フェロポリック風管を開発 し、岩盤掘進坑道における吸出し通気方式を確立した。こ の方式により、機械化岩盤掘進箇所の作業環境を第 1 管理 区分に改善することが可能となった。また、同時に、作業 能率も大きく改善された。しかしながら、本方式では、風
管の延長距離が $700 \mathrm{~m}$ 程度と短く、長距離掘進坑道への適用 は難しくなる。また、吸出し側扇風機の動翼の磨耗が激し く、定期的な更新が必要である。さらに、フェロポリック 風管の接続部の腐食、変形等の問題があり、これらの諸問 題の解決が望まれている。そこで、ガスの多い沿層掘進箇 所にも導入可能である移動式集じん方式の現場適用化を図 ることにした。この方式は、通気的には、吹込み一吸出し 組合せ方式（吹込みオーバーラップ方式）であり、1989年 〜 1991年に現場基礎試験を実施し、その防じん効果を確認 した。現場基礎試験の結果から、本方式の実用化を図る上 でのポイントは、下記 3 点と考えられる。

(1) 切羽の進行に合わせて、移動式集じん装置を逐次移設 すること。

(2) 防じん効果、及びガスの滞留防止を考慮して、風管の 最適配置を行い、これを遵守すること。

(3) 防じん効果、及びガスの滞留防止を考慮して、吸出し 風量 $Q_{1}$ 、吹込み風量 $Q_{2}$ 及び二股管からの吹込み風量 $\mathrm{Q}_{3}$ の配分を一定割合に保持すること。

移動式集じん装置（乾式で検討中）は、当初、固定式集 じん装置と同じく、処理風量 $500 \mathrm{~m}^{3} / \mathrm{min}$ 検討を行ったが、 現状技術では小型・軽量化することが難しいことが分かり、 現在、 $300 \mathrm{~m}^{3} / \mathrm{min}$ 以上の条件で設計を行っている。移動式集 じん装置の移動方法は、ベルトコンベアの終端部又は P C (パンッァーコンベア）に搭載して、切羽の進行と共に R H（口-ド ヘ多”））等で牽引する方法を検討中である。風量配分を一定 に保つためには、移動式集じん装置による吸出し風量は、 ほぼ一定と考えられるので、吹込み用扇風機側の風圧・風 量を切羽の延びに応じて、段階的に増加して行く必要があ る。そこで、昨年度、吹込み用扇風機として、出力周波数 を変更し、回転数を変化させて風量制御する防爆型インバ 一夕制御方式扇風機 $(55 \mathrm{kw} \times 2)$ を開発し、現在、現場試験 を実施中である。移動式集じん装置製作完了後、来年 3 月 には移動式集じん方式の現場試験を実施する計画である。 第 1 図に移動式集じん方式の設備配置の一例を示す。

（5）粉じん抑制型ドラムの開発

我が国では、長壁式採炭払のドラムカッター切削中の発 じん抑制には、一般的には、ドラム内高圧散水方式及びド ラム外散水方式が併用されている。ドラム内高圧散水方式 においては、ドラムに埋込んだ散水ノズルの口径の設計值 は、 $1 \mathrm{~mm} \phi$ 以下とされているが、坑内水の水質不良のため の水垢、内部及び外部からの異物等により、目詰まりがし

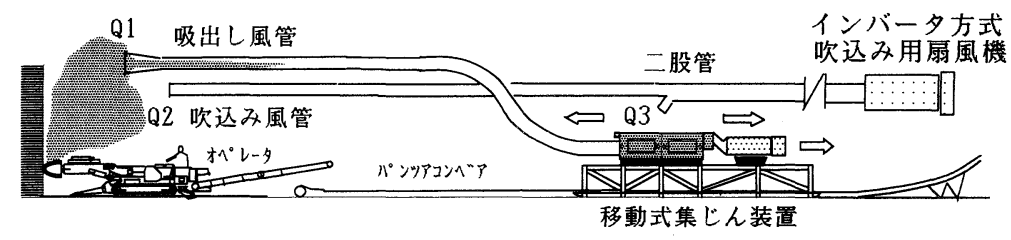

第 1 図 移動式集じん方式の設備配置の一例 
ばしば発生し、現場管理に困難を来した。そこで、より実 用的な粉じん抑制型ドラムを開発するために、海外文献の 調查を行うと共に、1992年〜1994年にかけてエアジェット 噴霧方式の現場基礎試験を実施した。海外文献調査等によ れば、ドラムカッター切削中の粉じん制御のポイントは、 下記の諸点である。

(1) ドラムの形状、回転速度及び切込み深さ

(2) 切削速度

(3) 切削ビットの形状、本数及び取付位置

(4) 散水圧力、散水ノズルの口径、個数及び取付位置

エアジェット噴霧方式では、噴霧粒径が小さくなるので、 吸入性粉じんの抑制効果は、高圧散水方式と較べ遜色がな いうえ、散水ノズルの口径も高圧散水方式に比べ大きくす ることが出来る。压縮空気用エアコンプレッサーはカッ夕 一搭載型とし、カッター本体の動力を利用した。両ドラム 共エアジェット方式ドラム内散水方式として現場試験を実 施したところ、排気道側ドラム用エアコンプレッサーのス トレーナが粉じんによる目詰まりにより、しばしば圧気圧 力が低下し、噴霧不良となった。また、エアジェットによ り、排気道側ドラムの天井際の視界が不良となった。そこ で、1995年に排気道側を、高圧散水方式に切り替え、高圧 散水一エアジェット噴霧組合せ方式とし、現場試験を再開 した。この方式では、噴霧状況が良好な時には、粉じん抑 制率は $90 \%$ 近くに達し、大いに期待が持たれた。本方式 の粉じん抑制型ドラムの仕様としては、切削ビットは、従 来のラジアル型を変更し、粉じん抑制型のポイントアタッ ク型とした。各切削ビットは大型化・強化型とし、ビット 数を 45 本まで低減した。ドラム回転数は $30 \mathrm{rpm}$ とし、発 じん量を抑制した。これは、我が国では最低回転数である。 散水ノズルの個数は 9 ケとし、口径は目詰まり防止を考慮 して、当初設計值は $5 \mathrm{~mm} \phi$ としたが、散水ノズルの取付位 置の工夫により、目詰まりが激減したため、逐次縮小して 最終的には $4 \mathrm{~mm} \phi$ とした。同じ種類のノズルであれば、口 径の小さい方が噴霧が安定することが、工場試験の結果明 らかとなったからである。

エアジェット噴霧方式の粉じん抑制効果の測定法は、エ アジェットを使用した場合と使用しない場合に、カッター 切削中の合計 15 分間、排気側払口から $15 \mathrm{~m}$ 離れた排気 道の一点で粉じん濃度を測定し、比較検討を行った。しか し、本測定方法では、余程測定条件に恵まれない限り、粉 じん抑制装置による抑制効果を明らかに判定することは出 来なかった。これは、我が国炭鉱の炭層条件は断層、合盤 などが多く、同一採炭箅所においても測定日が異なると、 発じん量が大きく変動するためである。また、エアジェッ 卜噴霧は、圧気圧力と散水圧力の変動等により、良好な噴 霧を長期間維持することは難しい。ストレーナの清掃及び 散水・圧気圧力の調整など、定期的にメンテナンスを行う ことが必要である。

\section{5. 今後の取り組み}

国内炭鉱坑内作業環境の実態調查、抑制対策試験につい ては、排気坑道と共に、入気坑道における粉じん発散状況 調查及び発じん源対策など、よりきめ細かな対策試験を実 施する計画である。また、国内のみではなく、経済発展の 著しいアジアの国々に対し、我が国のじん肺の予防と対策 技術を、移転することが可能かどうか検討するため、中国 等海外諸国の粉じんに関する実態調査を実施予定である。 測定器の開発に関しては、粉じん対策をよりきめ細かに実 施するため、粉じん濃度の集中監視化を促進すると共に、

個人暴露濃度測定法の導入を検討中である。集じん装置の 開発に関しては、移動式集じん方式の早期実用化に努める。 粉じん抑制型ドラムの開発は、これまで実施した試験結果 を参考にして、各炭鉣の自然条件に合致した粉じん抑制型 ドラムの開発が望まれる。

当然のことながら、粉じん抑制技術の開発に際し、粉じ ん抑制装置の防じん効果、実施状況を定期的に調查し、必 要なメンテナンスを行うことが望まれる。これらの調査で は、環境測定としての粉じん測定のほか、粉じん発散源の 防じん効果確認のためのデザイン・サンプリングによる、 粉じん測定が必要である。そのためには、自然条件の変動 に左右されない抑制効果の測定法、評価法を各現場で工夫、 開発し、粉じん抑制装置の防じん効果の維持を図ることが、 肝要であると思考される。

最後に、粉じん対策技術の開発に当たり、委員会、大学、 研究機関、メーカー、並びに各炭釷現場の関係各位に、数 多くのご協力、そしてご指導を頂いた。紙面を借りて深く 感謝の意を表する次第である。

\section{（参考文献）}

1) 釷業労働災害防止協会 : 鉱山における粉じん濃度測定マニュアル (1986、1995)

2) 房村信雄 : 粉じん対策の技術的体系 (1989)

3) 石炭技術研究所

: 鉱山保安技術調査委託事業成果報告書 (1986 1995)

: 粉じん対策調查報告書 (1995、1996)

: 石炭導入促進調査委託事業成果報告書 (1996) 